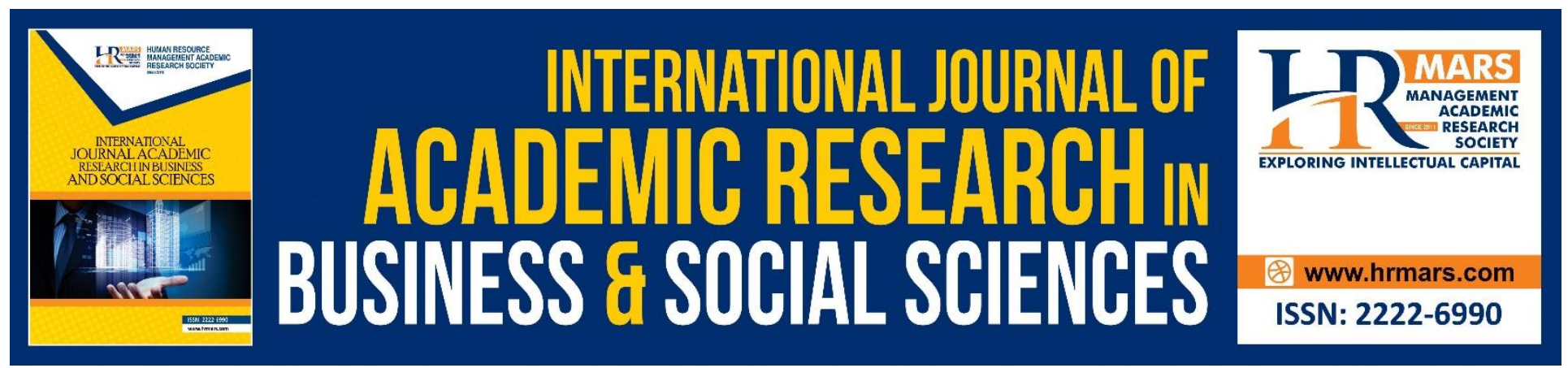

\title{
The Perception and Acceptance of Malaysians Ethnics on The Concept of 1 Malaysia and Nation Building: Online Media and Mainstream Media Coverage Meditation
}

Sara Chinnasamy, Mohd Roslan Rosnon, Nurathirah Yusof \& Jamilah Shaari

To Link this Article: http://dx.doi.org/10.6007/IJARBSS/v10-i16/9211

DOI:10.6007/IJARBSS/v10-i16/9211

Received: 09 October 2020, Revised: 04 November 2020, Accepted: 22 November 2020

Published Online: 20 December 2020

In-Text Citation: (Chinnasamy et al., 2020)

To Cite this Article: Chinnasamy, S., Rosnon, M. R., Yusof, N., \& Shaari, J. (2020). The Perception and Acceptance of Malaysians Ethnics on The Concept of 1Malaysia and Nation Building: Online Media and Mainstream Media Coverage Meditation. International Journal of Academic Research in Business and Social Sciences, 10(16), 423-445.

Copyright: (c) 2020 The Author(s)

Published by Human Resource Management Academic Research Society (www.hrmars.com)

This article is published under the Creative Commons Attribution (CC BY 4.0) license. Anyone may reproduce, distribute, translate and create derivative works of this article (for both commercial and non-commercial purposes), subject to full attribution to the original publication and authors. The full terms of this license may be seen

at: http://creativecommons.org/licences/by/4.0/legalcode

Special Issue: Youth and Community Wellbeing: Issues, Challenges and Opportunities for Empowerment V2, 2020, Pg. 423 - 445

Full Terms \& Conditions of access and use can be found at http://hrmars.com/index.php/pages/detail/publication-ethics 


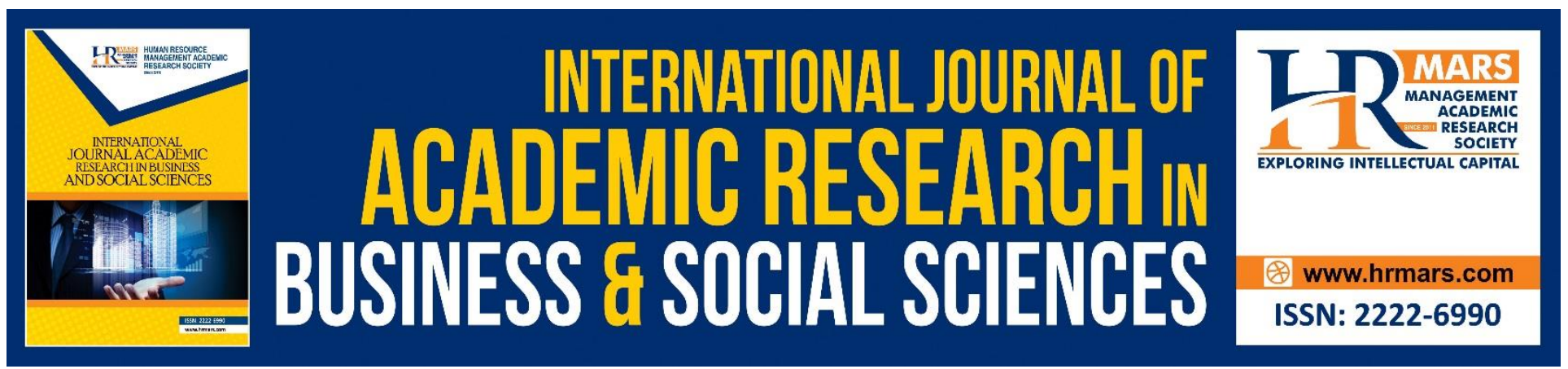

\title{
The Perception and Acceptance of Malaysians Ethnics on The Concept of 1 Malaysia and Nation Building: Online Media and Mainstream Media Coverage Meditation
}

\author{
Sara Chinnasamy ${ }^{1,2}$, Mohd Roslan Rosnon ${ }^{1,3}$, Nurathirah Yusof ${ }^{2} \&$ \\ Jamilah Shaari ${ }^{4}$ \\ ${ }^{1}$ Institute For Social Science Studies, Puta Infoport, Universiti Putra Malaysia, 43400, UPM Serdang, \\ Selangor, Malaysia, ${ }^{2}$ Faculty of Communication \& Media Studies, Universiti Teknologi MARA (UiTM), \\ Malaysia, ${ }^{3}$ Department of Social \& Development Sciences, Faculty of Human Ecology, Universiti \\ Putra Malaysia, 43400, UPM Serdang, Selangor, Malaysia, ${ }^{4}$ School of Health Sciences, Universiti \\ Sains Malaysia, Health Campus, Malaysia \\ Email:roslan_rosnon@upm.edu.my
}

\begin{abstract}
1Malaysia had been seen as a concept that will work in the plural community and to ensure the equality despite the racial groups and religion. Ever since the 1Malaysia concept was announced in 2009 by the $6^{\text {th }}$ Malaysian Prime Minister Dato' Seri Najib Tun Abdul Razak, there are lots of opinions and responds being voiced out towards this idea. With the slogan of 'People First, Performance Now", it urges Malaysians to stay united regardless ethnics and religions. The major aim of this conception is to create racial harmony and unity among its citizens (Malay, Chinese and Indians ethnics). This paper will analyze the people's perception and their level of understanding and acceptance towards 1Malaysia including their views on the introduction of 1Malaysia in early days and how multi-ethnic people interpretative this conception. The promotion of 1Malaysia can be widely seen in the traditional media and new media. Textual analysis and in-depth interviews methods have been used to identify the effectiveness of 1 Malaysia towards the country development and how the ruling government, Barisan Nasional (BN) response in promoting one identity to representing the country. Despite, the great promotion and educating the Malaysians on the 1Malaysia goals, many of them still criticize the government and not supporting its implementation. The 1 Malaysia is not only being criticized by the public, but also among the politicians especially from the Opposition parties. Yet, the ruling government, $\mathrm{BN}$ took an action by protecting 1 Malaysia and believing in it. The government stands strong behind this concept and put lots of effort in order for this to succeed.
\end{abstract}

Keywords: Malaysia, Government, Perception, Understanding. 


\section{Introduction}

Nation building is a procedure that requires bunches of exertion with a specific end goal to add to the soul of patriotism and solidarity to make a nation whose individuals share a typical personality. The significant point is to cultivate national solidarity by building up another country and a coordinated race. In Malaysia, nation- building has been started since the independence of Tanah Melayu. Malaysia consists of Malay, Chinese, Indians and Bumiputera. Malaysia's multi-ethnic culture, in this way, is portrayed by an ever-introduce and perpetually developing pluralism, to be sure positive and innovative one. Being a multi- ethnic country, the process of nation- building can be challenging. This is one the reason, the $6^{\text {th }}$ Prime Minister Dato' Seri Najib Tun Razak introduced '1Malaysia' with the aim of stressing on national unity and ethnic tolerance also as a part of nation building. The concept was introduced in 2009 as an idea to encourage solidarity among Malaysians with diverse races in view of vital quality which ought to be rehearsed by each Malaysian (Prime Minister Office, 2010). The most essential perspective in 1Malaysia is the comprehension of every individual from distinctive ethnics. The value of 1 Malaysia as verbalized by Dato' Seri Najib Tun Razak are accepted, a culture of excellence, huminity, perseverance, loyalty, education, integrity and meritocracy (Ashykin et al.,2015). All of these values are needed under the 1Malaysia concept.

The unity pictured in 1Malaysia progression is different from other assimilation concept or idea practiced by other countries where the identities of other ethnics are erased and substituted with a same one national identity. This concept acknowledges and regards the personalities of every ethnics and has no aim of transforming it. 1Malaysia is the government's continuous effort in building the nation's agenda with the approach in fostering unity amongst the multi-ethnics in Malaysia (Harris \& Han, 2020; Ismail \& Ahmad, 2014). The question is, whether how far the objectives of 1Malaysia can be realized, and will the Malay, Chinese and Indians perceive themselves as 1 Malaysian. This can be a real challenge for the government to achieve since the independence of Malaysia. National character is the foundation of solidarity is still dubious to the subject.

1Malaysia is as a way to strengthen the relationship of each race in this country in order to achieve the status of developed country by 2020. The main objective for the implementation is for the nation unity (Suhadi \& Abd Rahim, 2018; Suhana, 2012). As Malaysia is a diversify nation with various ethnics live together in one country, the $6^{\text {th }}$ Prime Minister feels the need to gain and sustain the nation unity. Yet, 1Malaysia concept has faced lots of negative responds among public especially the believe the concept will bring vested interest to certain races. Malay, Chinese and Indian have build up different ideas on this concept. They believed this concept will against their rights and will only increased the sensitivity among people. Many issues has been raised on 1Malaysia due to different perceptions made by people yet affected outsider's view on Malaysia's harmony. If the country is facing the trust issue, hence how the economy development can be established and achieve its mission in 2020? Thus, it is an important task to explore people's perception towards this concept since it was introduced and to what extent it was effective and helpful towards the country growth. At the same time, what are the ruling government, BN responses towards people arguments and confrontation and how it managed the critics and opponents on it.

Therefore this paper will discuss what people's perception and their level of understanding and acceptance towards 1 Malaysia including their views on the introduction of 1Malaysia in early days? 
INTERNATIONAL JOURNAL OF ACADEMIC RESEARCH IN BUSINESS AND SOCIAL SCIENCES

Vol. 10, No. 16, Youth and Community Wellbeing: Issues, Challenges and Opportunities for Empowerment V2. 2020, E-ISSN: 2222-6990 @) 2020 HRMARS

How multi-ethnic people interpretative this conception? How is the promotion of 1Malaysia in the traditional media and new media and what is the respond of the 1Malaysia from the public, and politicians and how the government respond by protecting 1Malaysia?

\section{Nationalism}

Anderson (1991) work on nationalism characterizes the country as, an 'imagined political group' and envisioned as both naturally constrained and sovereign. It is envisioned in light of the fact that the individuals from even the littlest country will never know a large portion of their kindred individuals, meet them, or even know about them, yet in the brains of each life the picture of their closeness. Malaysia is a multiracial country that consists of Malay as a majority group followed by Chinese and Indian ethnics. These three leading groups need to form a concrete understanding between them in order to develop a stable economic for the country as well as unity like what has been stated in Wawasan 2020. Yet, they have different beliefs and some of them are still holding grudges on what happen on 13th May 1969, the unity is still away from what the ruler had planned earlier. Anderson (1991) work explain how and what are those struggles in creating a stable nation. Incorporating distinctive races and makes them trust they require one another as one most likely requires a great deal of exertion and time as it is another sort of country state accumulated Americans with diverse ethnicity, society and dialect. Besides, highly contrasting took an additional 100 years for combination. This can be demonstrated with Anderson (1991) hypothesis that patriotism of multiethnic must be made by trusting patriotism needs more than comprehension. Despite the fact that the state is exceptional, the execution of the thought takes more than comprehension. An article entitled 'Country Building' contends that keeping in mind the end goal to have a peace country fabricating, the ruler must join more than simply the Western expansion of majority rules system (Stephenson, 2005). By executing voting framework, free market improvement and expanding the GNP per capita just prompt unsteadiness of the nation.

Anderson's hypothesis demonstrated how a country can be loaded with pointless ideological with regards to religion. Native self-government in the United States, Americans need to take after the points of confinement of radicalism and to recognize their lifestyles that are not a portion of American's character. Despite the fact that country building is concentrating on its nation advancement, the United States government does not need to control their resident from act the way they need insofar as it's not intersection human's standard and break nation's tenets. The changes and more noteworthy territorial compromise can be created more through multilateral country building regardless of one-sided endeavors (James, 2003). Thus, to accomplish an abnormal amount of country building, the nation must put a great deal exertion than depend on restricted.

One-sided endeavors are tedious. The nation will eye the task of country building at one thing at one time. In the event that the undertaking neglects to meet its objectives, the ruler has squandered their vitality and cash for quite a while with no reinforcement arranges. On account of Russia, the early formation of a realm (well before the procedure of Russian country building started) the domain's territory based character and the subsequent abnormal state of common social impacts and digestions in the middle of winners and vanquished to some degree obscured the sentiment contrast between the magnificent individuals and other subject of domain. Ethnicity and Foreign arrangement: Uzbekistan and 'Uzbeks Abroad'. While, Indonesia has experienced huge changes on 
INTERNATIONAL JOURNAL OF ACADEMIC RESEARCH IN BUSINESS AND SOCIAL SCIENCES

Vol. 10, No. 16, Youth and Community Wellbeing: Issues, Challenges and Opportunities for Empowerment V2. 2020, E-ISSN: 2222-6990 @) 2020 HRMARS

its progressing basic and political changes in 1997 and rising up out of its political and monetary emergency. Sukarno had made ideological adversaries, an idea to solidify and fortify the bonds among Indonesians to end up a solid country, unbiased and pick up appreciation from different nations. Despite the fact that he has administered Indonesia as a leader, all the venture of country and character building he'd been highlighted, however neglect to add to a solid economy in Indonesia (Efendi, Nurmandi, \& Agustiyara, 2017). Nation building, State building, and the street to majority rule government: Political advancement in 60 years of the general population's republic, he expressed that China was not looking forward as a "present day" state, but rather a 'solid country', around then the nation was being ruled by the West and the worldwide wave hit each rising cutting edge country state (Wang, 2009). After Mao Zedong led the country, China had its economic, social and international dimensions. Singapore is focusing on modernity, development and economic success after being ejected from Malayan Union and become independent in 1965 (Ortmann, 2009). Pragmatic values are adopted by the government to have a rapid economic growth and discarding the cultural value. At that time, Singapore's government believed that all the cultural aspect is a huge obstacle in order to develop the country itself.

It is trusted that a down to business esteem has helped Singapore a considerable measure in building up its nation. Singapore has a little populace with multi-ethnic race, it is fairly sufficiently hard to produce monetary as one. On one hand, little populace is the issue. The little populace has offered Singapore some assistance with focusing and more imaginative on the best way to create wage for its littlest nation. That is the motivation behind why Singapore isn't giving much consideration on the social viewpoint, however it a nation with multi-ethnic. Decision world class' endeavor to firmly relate its accomplishments with the survival of the country has succeeded. On the other hand, this additionally implies the legislature has not been fit for producing a solid feeling of group which would be useful in times of monetary decay. Singapore has utilized the English dialect approach as a part of instructive, regulatory framework and authority dialect (Chew, 2007). This made Singapore be an issue of the way to be Singaporean and the part of English dialect in the nation as its national social personality. From this announcement, Singapore has additionally set it country implementing so as to build English Language into its nation's framework (Ha, Kho, \& Chng, 2013) Singapore has "imported" English as its overwhelming dialect in light of the fact that the ruler trusted that by utilizing it the nation can go assist and enter universal markets and upgrade their financial part, which can enhance their nation salary.

\section{Nation Building Making}

The production and implementation of education policy in Malaysia is based on ethnic considerations. The government attempts to fulfill the demands and needs ethnic group should be handled carefully as it may touch ethnic sensitivities and interest (Hazri \& Raman, 2012; Menon, 2020). In Malaysia's real dialect arrangements encompassing Bahasa Malaysia and English as the medium of guideline (MOI) in schools and colleges since its autonomy are particularly drawn on. We contend that the dialect banter in Malaysia is to a great extent an emotive one that conveys verifiable things which nobody is yet prepared to dispose of and until such time, it will keep on speaking to a country partitioned by patriotism, race-based governmental issues and globalization. Non-urban in Malaysia interested on Bahasa Malaysia as an account of the impact of patriotism and their demeanors towards English is undecided, (Altbach \& Knight, 2007). Anderson's claims that 
INTERNATIONAL JOURNAL OF ACADEMIC RESEARCH IN BUSINESS AND SOCIAL SCIENCES

Vol. 10, No. 16, Youth and Community Wellbeing: Issues, Challenges and Opportunities for Empowerment V2. 2020, E-ISSN: 2222-6990 @) 2020 HRMARS

nationalism can be achieved if the community reduces their privileged access o particular script language. The common reality of education contributing in all societies to the creation of the imagined community which is the nation (Anderson, 1991). To unite ethnic communities as one, the government has come out with 'vision schools', in order to promote integration of various races at school level and develop effective relationship between different communities among school children. The idea of 'Vision Schools implies that a few distinct sorts of schools and organizations are put in the same building (Ministry of Education Malaysia, 1995). This will help the students to mingle and study better with other ethnics.

Despite ethnicity issues and sentiment, the government is facing diverse cultural communities that have different beliefs and religious under one nation. There is a low level of incorporation between the Malays and the Chinese in view of social and social comprehension (Wan Teh, 1983). Lots of questions have been raised on how the one nation spirit can be achieved in education whereas ethnicity issues keep arising openly. An addressed whether the reconciliation soul is sufficient to demonstrate the viability of the instructive strategy in light of the fact that there are proceeding with issues of ethnicity out in the open and private talks (Sufean, 1993). As issues of ethnic keep repeating, the potential of Malaysian to perform as one nation is probably impossible. The multiethnic groups in Malaysia might remain contrast due to the way that protected and approach rehearse underlines a Malay-non-Malay strife on all monetary, social and political measurements (Cheah, 2003; LinSheng, 2003; Radzlan et al., 2018).

Ethnicity is attributed during childbirth, getting from the kinfolk and faction structure of human culture, and subsequently something pretty much altered and perpetual. Ethnic ties can exist when different ethnic or races shared the same value such as culture, tradition, history and descendants (Baharuddin, 2008; Radzlan et al., 2018). For example, Malay and Indian share a common wedding culture. This similarity that exists can be the foundation of ethnic relations. The goal of building a harmonious society would be even more complex to achieve as the ethnic groups are keen to compare each other from the aspects of race such as skin color, traditions, origin, language or even arts (Wan Husin, 2011). On a fundamental level, all country building procedures are social mediation as the Center sets up a specific character on the outskirts or at the end of the day, the first class makes a national personality for whatever is left of the populace.

Anderson expressed his consideration on the multi ethnic realm keeping in mind the end goal to accomplish this nationalism. Nationalism in multi ethnics nation is a complex task to accomplish due to the distinction of society and accept. Malaysia comprises of Malay, Chinese, Indians and Bumiputera. Malaysia's multi-ethnic culture, accordingly, is portrayed by an ever-exhibit and perpetually developing pluralism, undoubtedly positive and inventive one. Thus, the social division exists inside of Malaysian culture, for instance, ethnics, sub-ethincs, and semantic furthermore territorial class. The effect of the social division can be either positive or negative that can contribute towards Malaysia's social solidness. The endeavors of the nation-aking in Malaysia started decisively through an unlimited arrangement of dealing between the diverse ethnic gatherings in Malaysia. Malaysians are currently certain that they can request change without gambling ethnic strife. They additionally realize that enough weight can make the Government bargain. 
INTERNATIONAL JOURNAL OF ACADEMIC RESEARCH IN BUSINESS AND SOCIAL SCIENCES

Vol. 10, No. 16, Youth and Community Wellbeing: Issues, Challenges and Opportunities for Empowerment V2. 2020, E-ISSN: 2222-6990 @) 2020 HRMARS

It is clear that the quality of the Malaysian multi-ethnic culture lies its inventive capacity to survive an "arranged presence", changing in a cognizant way a disagreement to accord through a serene and a socialized exertion directed at all levels of society. Malaysia will stay one of only a handful couple of countries on the planet today, whose experience and track record in managing numerous ethnicities and numerous societies is a valuable one. With the historic moment of 13 May, Malaysia had experienced races revolt and highlight the issue of solidarity and this had turned out to be a great deal more hard to unite every one of the races. With the multi-ethnic, multi-lingual, and multireligious organization of the populace, national solidarity remains the primary expressed target of financial, social and national improvement. Malaysia needs to give careful consideration and concentrating more on multi-ethnics as it can prompt patriotism that they need to accomplish. To include the multifaceted nature of country building or national-personality development in Malaysia, the impact of imperialism under the British muddles the procedure of country building. Since the pilgrim days, the British had presented the 'separation and guideline' which every one of the races have been put in distinctive field of calling. This adds to the issue of country building in Malaysia. In any case, the administration attempts their best to battle this continuous issue.

The idea of country building in Malaysia tries to fortify connections among ethnic and guarantee Malaysians sow the seed of solidarity as revered in the national standards. Living in a multicultural society requires a high level of understanding and respect of those from other cultures. The standard purpose of administering multiculturalism in Malaysia is to keep up national joining in which all their diverse social gatherings could live near to each other while keeping up their own specific novel characters. Multiculturalism is characterized as the conjunction of assorted societies incorporates racial, religious or social gathering. It is additionally showed in standard conduct, examples of speculation and correspondence style. Multicultural can be found in Malaysia as it has different races living respectively in one nation. National solidarity has been one of the essential topics for country building following the freedom of Malaysia. Good relationship and understanding between each ethics are very important as we live in one country with lots of races. Thus, the relationship between ethnics is the main objective in the process of nation building (Camara, 2002). Without the mutual understanding and tolerance, Malaysia will face difficulties in achieving the mission.

\section{Methodology}

A case study research design has been used. This type of research design has been used widely in social science, psychology, anthropology and ecology. It is very useful method as it can test theoretical models and used it in real world situations. It also an in depth study of a particular condition that commonly used by researchers rather than conducting statistical surveys. Besides that it can be a handful method of testing scientific theories and models, whether both of this combination can actually work or not in the real world.

This research applies qualitative data collection methods. There are three types of methods that have been used: in depth interview, observation method and documentation reviews. In depth interview is commonly used by researchers where they conduct intensive individual interviews of a small number of interviewees as an alternative to find out their opinion about a particular idea or situation (Tewksbury, 2009). It is very flexible and continuous, where the researcher will get an opened ended answers from the interviewee compared to quantitative method which just get random result from 
INTERNATIONAL JOURNAL OF ACADEMIC RESEARCH IN BUSINESS AND SOCIAL SCIENCES

Vol. 10, No. 16, Youth and Community Wellbeing: Issues, Challenges and Opportunities for Empowerment V2. 2020, E-ISSN: 2222-6990 @) 2020 HRMARS

randomly pick respondents. Besides that, in- depth interview result will contribute to the strong content and better result because every single detail like phrases will be counted. In-depth interview results narrow respondents and only selected and professional respondent been chosen. It is also a good way of method to gain specific perspectives that will go through the deeper research aim. Indepth interviews have been conducted with 9 respondents from scholars group, non-govermental organization (NGO), and government sector. These respondents had been divided into three groups individually among multiracial scholars, NGO and government officials.

Textual analysis is another path for analysts to assemble data about how other people comprehend the world. It is a technique - an information get-together process - for those specialists who need to comprehend the routes in which individuals from different societies and subcultures understand who they are, and of how they fit into the world in which they live. It is a method used to describe and interpret recorded or visual message. Textual analysis is a way to significantly observe cultural artifacts or text to ascertain the meaning. It is a way for the researcher to gather information and understand the ways in which various cultures or subcultures make sense of each other. The function of textual analysis is to express content, structure and roles of the messages contained text. By using a textual analysis, the researcher will able to identify and analyze the text to add to the findings. In this research, textual analysis have been used to interpret the messages from four mainstream newspapers which is Berita Harian, Utusan Malaysia, The Star and News Straits Time. Apart from mainstream newspapers, two online news portal, Malaysiainsider.com and Malaysiakini.com were analysed too. 1Malaysia has been a hot topic and were featured in every newspaper to promote the concept. Textual analysis will help to examine the connection between the concept and the outcome that can be found in those media articles.

\section{Research Findings and Discussion News Mediation on 1Malaysia}

Thematic analysis was used to analyze the theme that appears in the online news portal. Thematic analysis is a systematic approach to the analysis of qualitative research that involve identifying themes or patterns (Lapadat, 2010). Anderson (1991) explained that thematic content analysis is a descriptive presentation of qualitative data and the data may be taken from the interview transcript collected from the research participants or identified texts regarding the research topic. Thematic analysis portrays the thematic content by identifying the common themes in the text provided for analysis. It is the most foundational of qualitative analytic procedures. Thematic analysis does not deal with the complexities of interpretation and the hermeneutic aspects meaning. It is suitable for researchers who wants a simple, clear-cut answers to the research questions. This statement had been supported by another scholar Braun and Clarke (2006) arguing that thematic analysis does not require detailed theoretical and technological knowledge of approaches, and is suitable for those beginner researchers. As the thematic analysis is more to descriptive structure, research focuses on the textual data and analyze using the steps provided. The answer will be analyzed in details in order to get the specific conclusion from the findings. Anderson's work on nationalism has focused on three important components which is racial harmony, unity and also nation building. These components will be the important themes for the analysis and will be further explained. 
INTERNATIONAL JOURNAL OF ACADEMIC RESEARCH IN BUSINESS AND SOCIAL SCIENCES

Vol. 10, No. 16, Youth and Community Wellbeing: Issues, Challenges and Opportunities for Empowerment V2. 2020, E-ISSN: 2222-6990 @ 2020 HRMARS

\section{Promoting Racial Harmony}

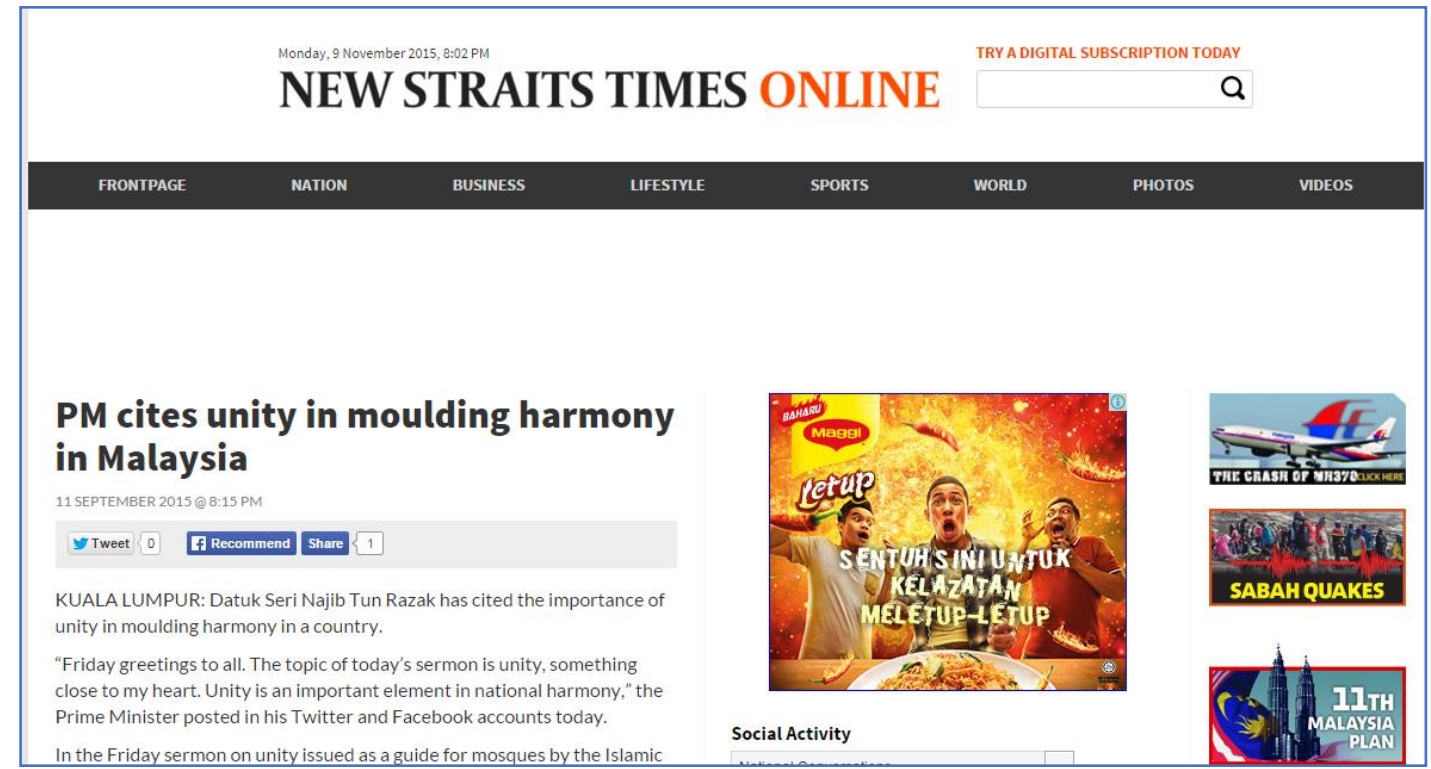

Figure 1: National Harmony

(Source: New Straits Times, 11 September 2015)

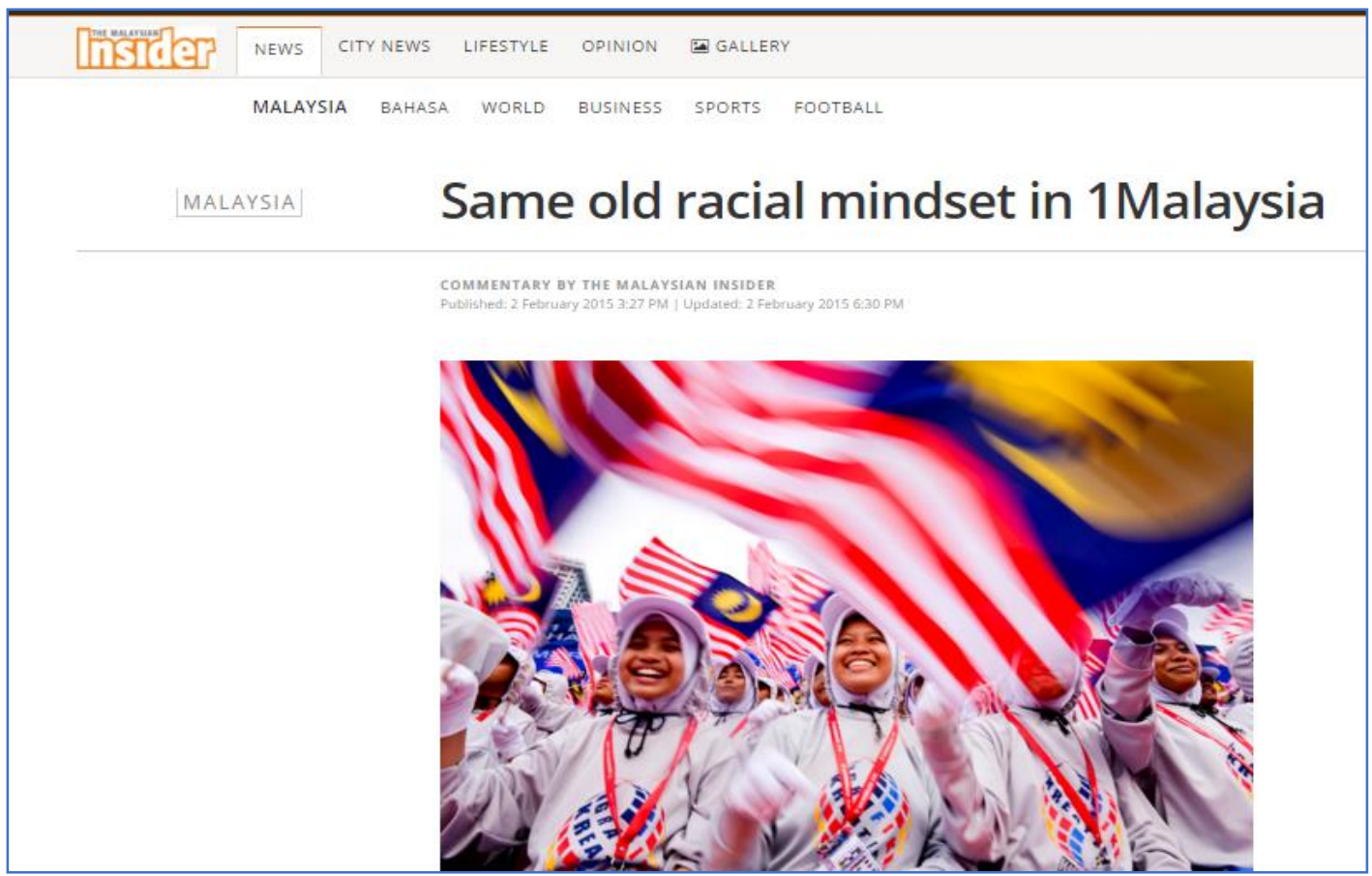

Figure 2: Same Old Mindset in 1Malaysia

(Source: Malaysianinsider.com, 2 February 2015) 


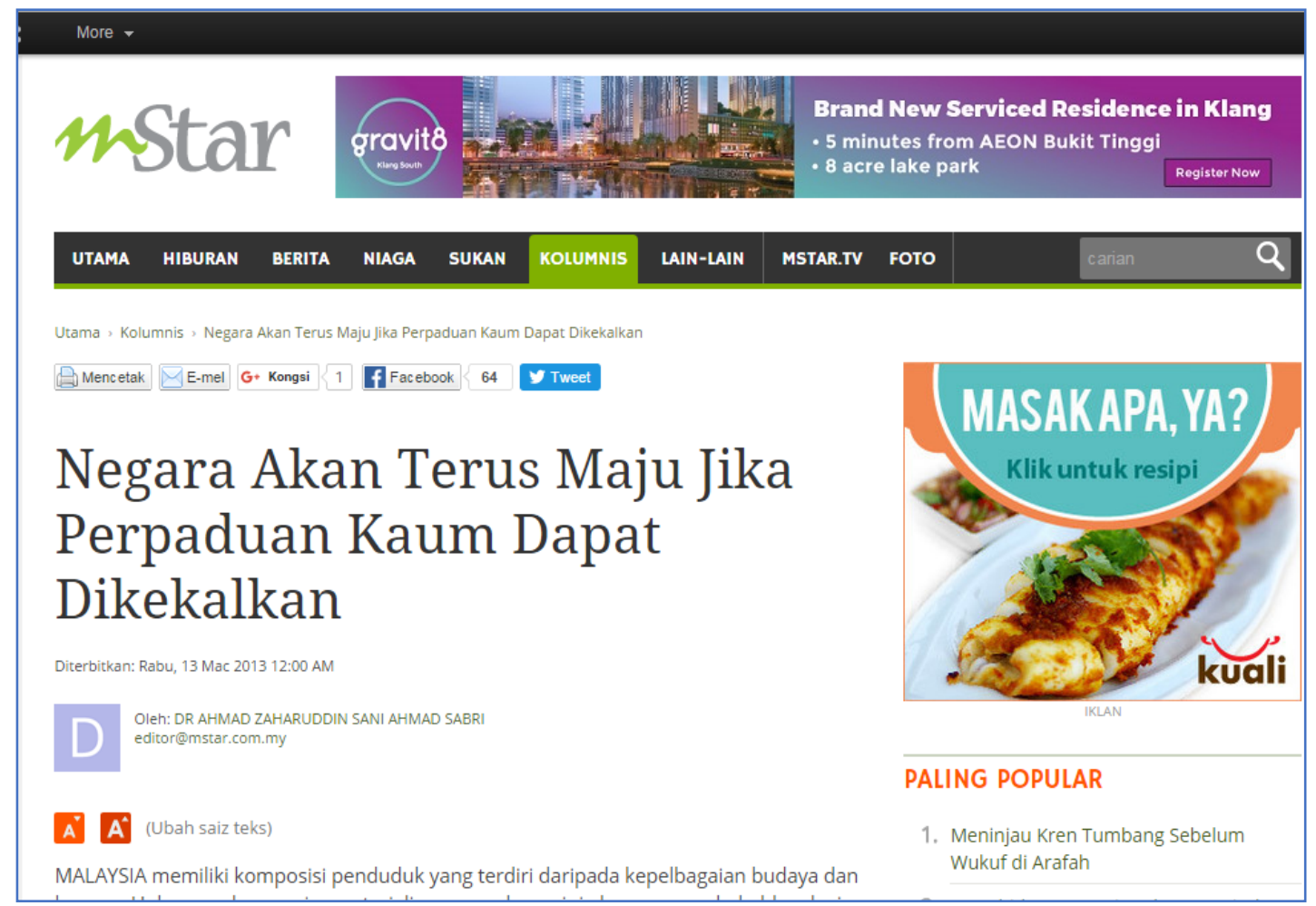

Figure 3: Racial Harmony

(Source: The Star, 13 March 2013)

Based on the above samples, it can be seen that the Star is trying to promote and strengthen the racial harmony in Malaysia. The main objective of 1 Malaysia is to foster racial harmony and print mainstream media is promoting the racial harmony among Malaysians. Anderson believes that print capitalism is needed to emerge the nation and claims that it was print capitalism which allowed for the development of these new national cultures and created the nation eventually. Malaysia government is trying to utilize the print media to urge its citizens to create racial harmony despite the racial differences in order to successfully build the nation that they desire through the 1Malaysia concept.

"We have celebrated 51 years as Malaysian but to some people, we are still in the racial silos of Malay, Chinese, Indian and others. And with that comes all the stereotypes of each race"

(Malaysianinsider.com, 2015)

Based on the Malaysianinsider.com 2 February 2015's news, the racial mindset still persists despite the 1 Malaysia campaign, which was brought up by the $6^{\text {th }}$ Prime Minister Dato' Seri Najib Razak. People still have the stereotype against other races, even until now. The implementation of 1Malaysia seems to not work well and gradually had impacted on Malaysian. The journalist claimed that this phenomenon happened after the 2008 General Election where the most of the citizens whether Malay, Chinese or Indian losses their trust with the government and the BN lose their state to the 
INTERNATIONAL JOURNAL OF ACADEMIC RESEARCH IN BUSINESS AND SOCIAL SCIENCES

Vol. 10, No. 16, Youth and Community Wellbeing: Issues, Challenges and Opportunities for Empowerment V2. 2020, E-ISSN: 2222-6990 @ 2020 HRMARS

opposition party and saw that the majority decreases to less than two-thirds in the federal parliament. They do not see that the concept of 1Malaysia works in creating racial harmony in the society. Thus, it is important for the government and its people to put aside their differences and work together to achieve the unity.

\section{The Importance of Unity}

Unity is another important component in 1Malaysia concept. Based on the Malaysiakini.com's article, Malaysia has to achieve national unity in spite of our diversity. The news shows that unity is essential for a multicultural country like Malaysia in order to sustain the harmony and peaceful society. Malaysia had faced many social challenges to create unity among its people and by implementing the 1Malaysia concept, it can help them to achieve the unity.

"Usaha-usaha itu diteruskan pula oleh Perdana Menteri atau pemimpin-pemimpin seterusnya hingga ke hari ini di bawah pimpinan Dato' Seri Najib Tun Razak. Jika dahulu kita disajikan dengan konsep perpaduan kaum atau integrasi nasional, tetapi hari ini. Satu Malaysia adalah pengukuhan kepada dasar- dasar yang releven yang dibentuk dan diamalkan selama 52 tahun ini.

"The efforts were being continued by the Prime Minster or the subsequent leaders to this day under the leadership of Dato' Seri Najib Tun Razak, in the past, we are presented with the concept of unity and national integration, but today, Malaysia is a strengthening of the relevant policies established and practiced for the past 52 years"

(Utusan Malaysia, 2009)

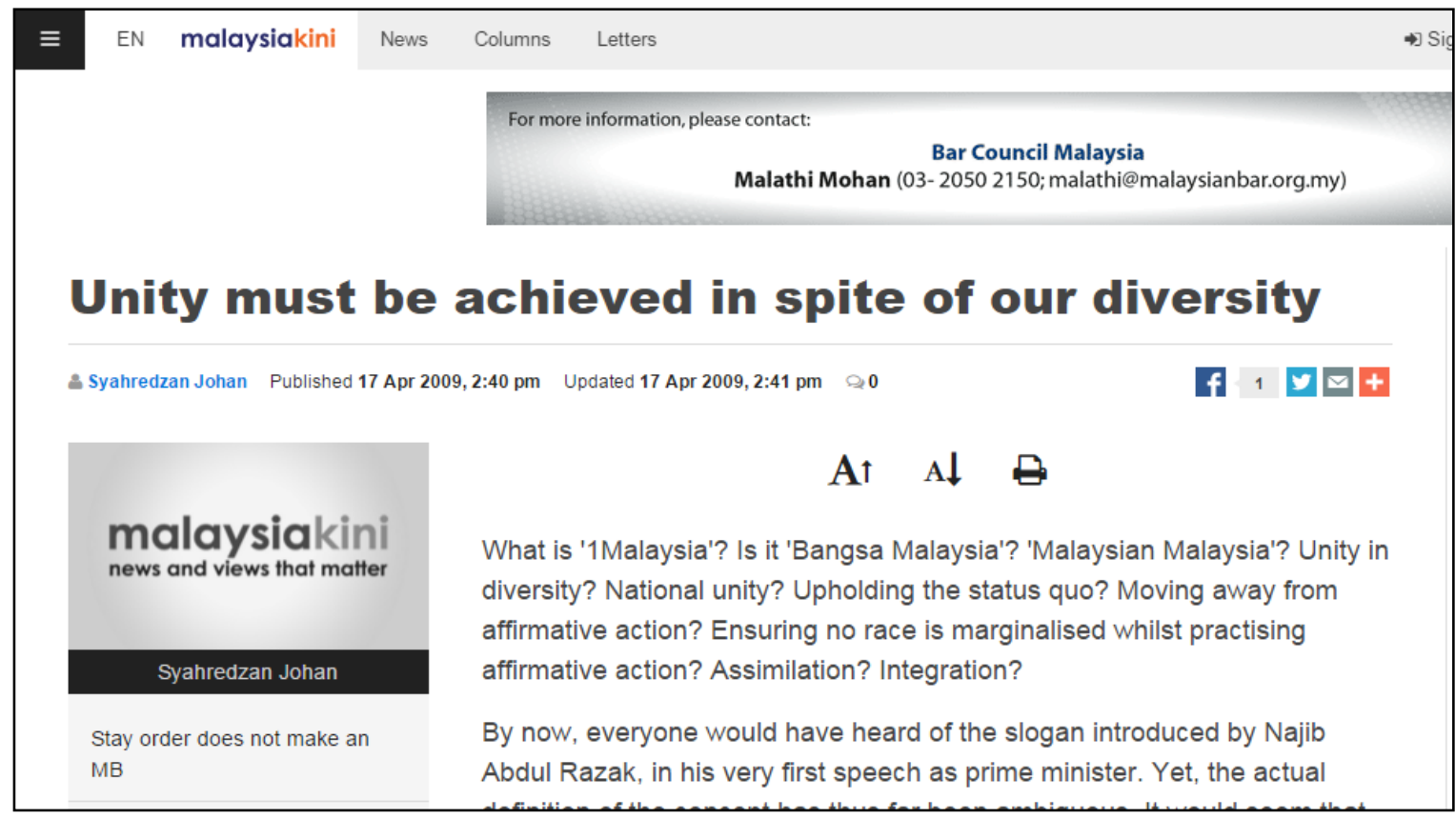

Figure 4: Unity in spite of our diversity

(Source: Malaysiakini.com, 17 April 2009) 
INTERNATIONAL JOURNAL OF ACADEMIC RESEARCH IN BUSINESS AND SOCIAL SCIENCES

Vol. 10, No. 16, Youth and Community Wellbeing: Issues, Challenges and Opportunities for Empowerment V2. 2020, E-ISSN: 2222-6990 @ 2020 HRMARS

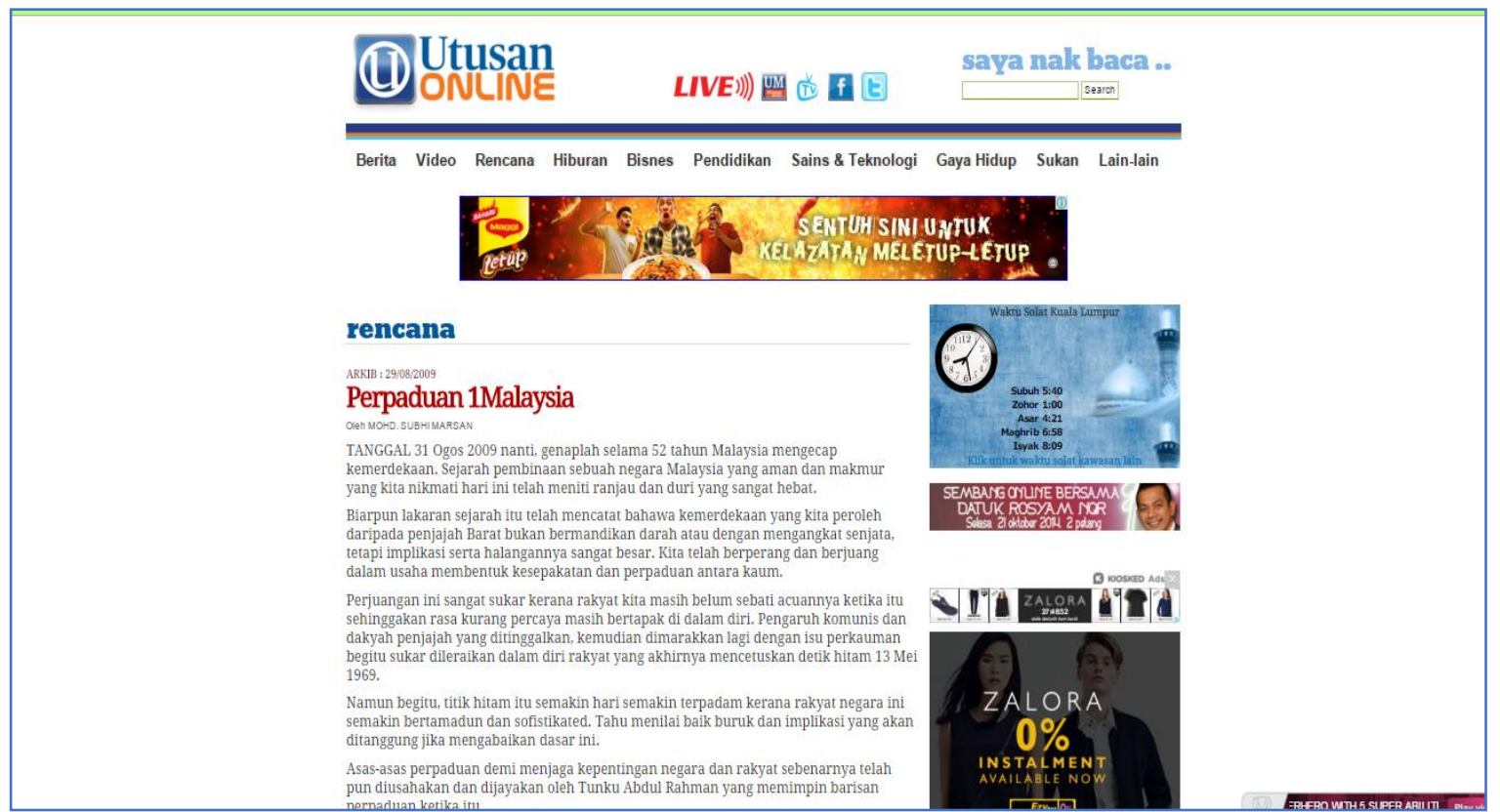

Figure 5: 1Malaysia Unity

(Source: Utusan Malaysia, 29 June 2009)

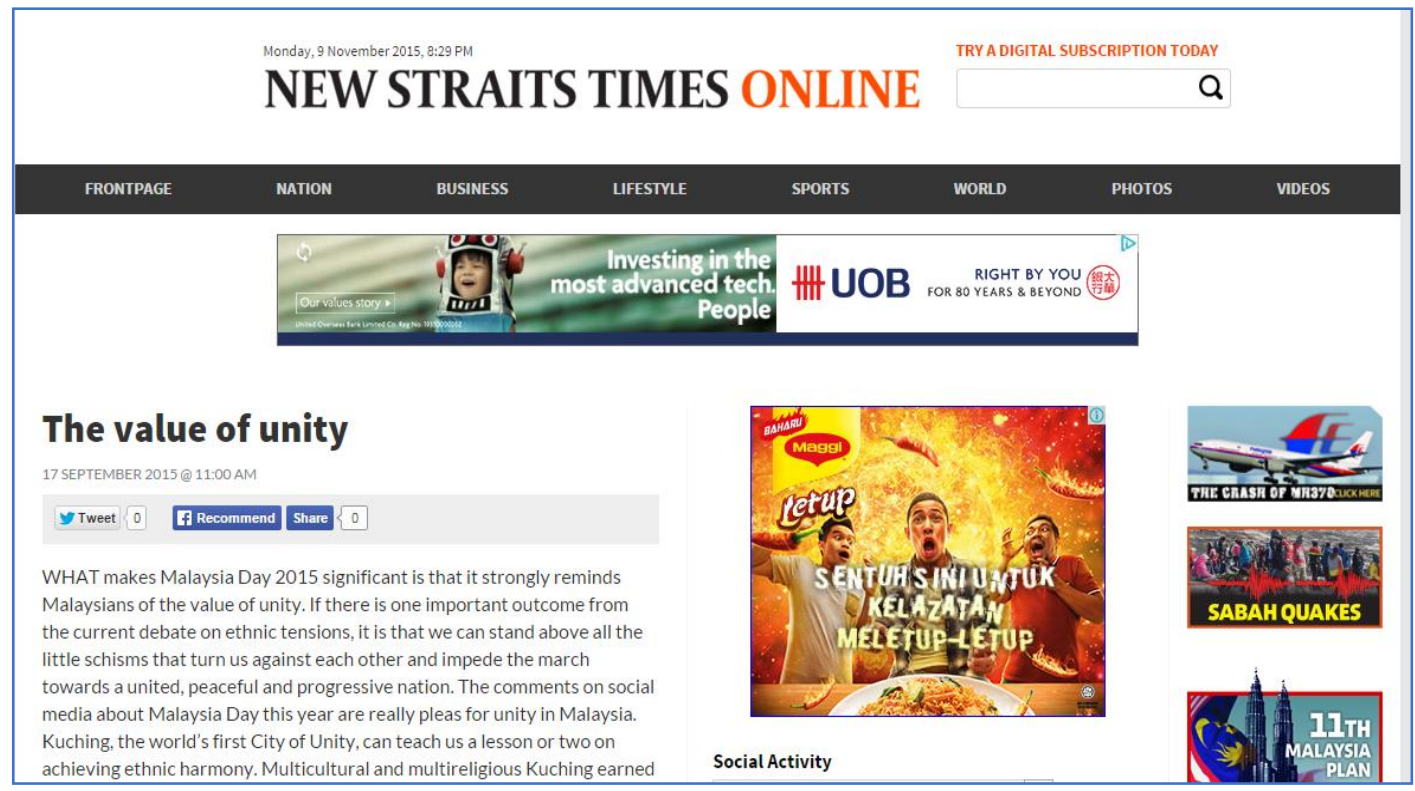

Figure 6: The value of unity

(Source: New Straits Times, 17 September 2015) 


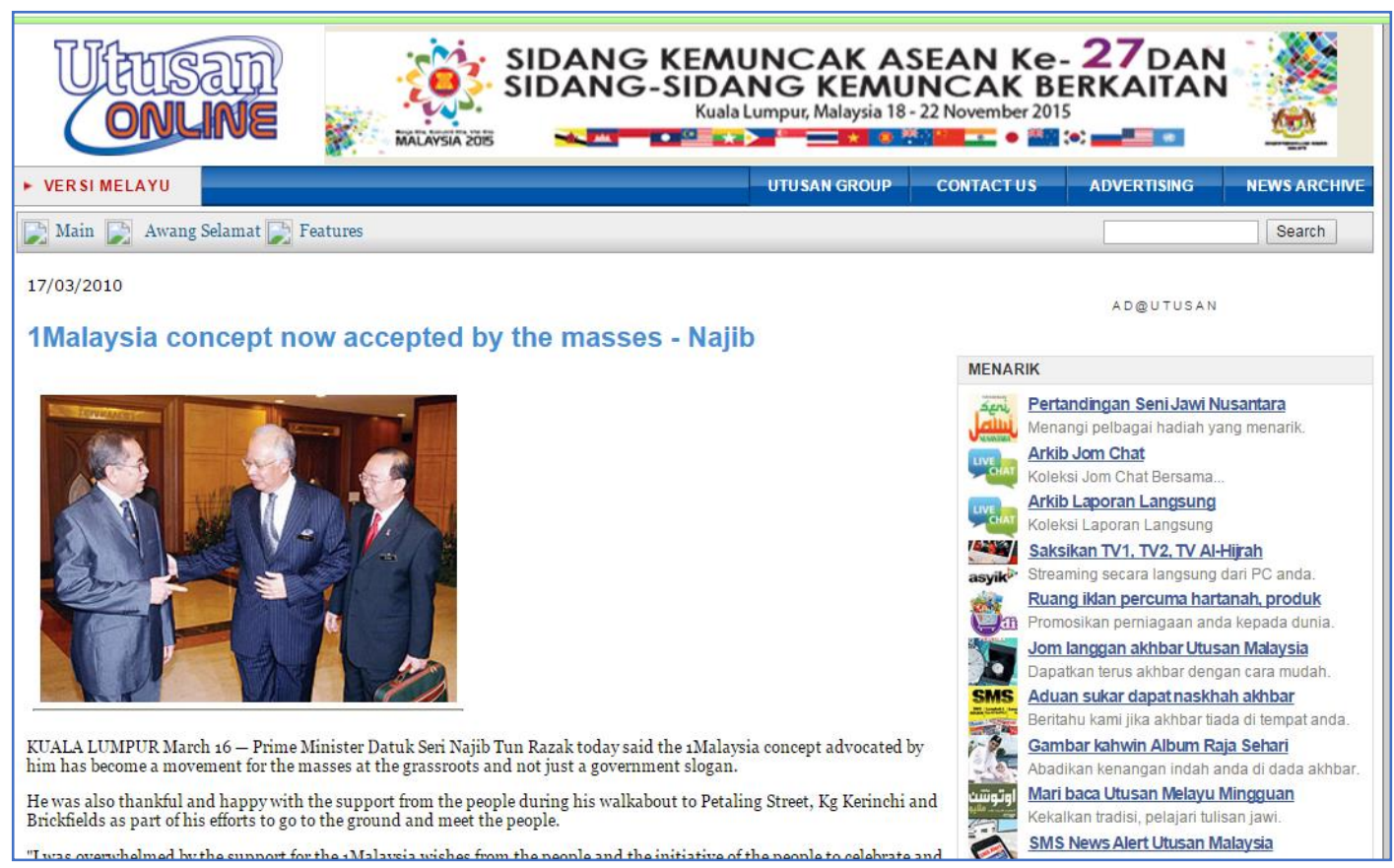

Figure 7: 1Malaysia now accepted by the masses

(Source:Utusan Malaysia, 17 March 2010)

While, Utusan Malaysia's news refer to the initiatives taken by the $6^{\text {th }}$ Prime Minister to sustain the degree of unity among people. The concept is to strengthen all the efforts made by the previous Prime Ministers as an ongoing effort that being continued since independence 1957. Anderson (1991) stated that attention on the multi ethnic empire is the best way to achieve nationalism. Nevertheless, achieving nationalism in the multi ethnics country is complex due to the difference of culture and believe. This the reason why the country has to focus on the unity before achieving the nationalism stage. As the 1Malaysia slogan says ' people first, performance now', 1Malaysia is aim to unite the people regardless of ethnic diversity or religious believe can be seen as the government took many initiatives to get its people to stand together. Dato' Seri Najib explained that the 1Malaysia concept was implemented under two main aspects: firstly, the assimilation of core elements of unity and, secondly, the assimilation of the aspiration values. This is an essential apart from the principles of nationhood which is based on the Federal Constitution and National Ideology. This is the important aspects that need to take into consideration in creating the unity.

\section{Nation Building}

Apart from the racial harmony and unity, nation building is also one of the important components. Based on the New Straits Times's news, it is a serious need for nation building making. Nation building in Malaysia is an effort to develop the spirit of patriotism and solidarity to create a country that shares a common and identical identity. The unity of its people will determine and channeled towards the development of a country. The process of nation building requires uniting different community ethnics in which, later on will shape the future ethnic relation in Malaysia has been seen through the concept of 1Malaysia. In order to achieve the goal of the nation- building, the government first needs to take all of the aspects such as politics, economy and social a priority. This will then result in the 
INTERNATIONAL JOURNAL OF ACADEMIC RESEARCH IN BUSINESS AND SOCIAL SCIENCES

Vol. 10, No. 16, Youth and Community Wellbeing: Issues, Challenges and Opportunities for Empowerment V2. 2020, E-ISSN: 2222-6990 @ 2020 HRMARS

unity among the major ethnics in Malaysia. The effort made by the government in facing the difficulties of nation-building can be seen through 1Malaysia. The process of nation- building require lots of efforts because of the nature of Malaysian society which is pluralist society. Anderson believes that it is common ideas and preconceive bonds of camaraderie shared by the people that unify them and form the nation. Essentially, Anderson states that, the nation's geographical boundaries meant little; the nation was defined by its common ideas and beliefs. In the case of 1Malaysia, the government tries to create one identity that represents all of the ethnics and race for Malaysia:

"DAP parliamentary leader Lim Kit Siang today refuted Prime Minister Najib Razak's claim that 1 Malaysia is a nation- building initiative to foster unity among Malaysians. Twenty months since the introduction of Najib's 1Malaysia, People First, Performance Now slogan, instead of giving Malaysians a new sense of being Malaysian, the reverse has taken place"

(Malaysiakini.com, 2010)

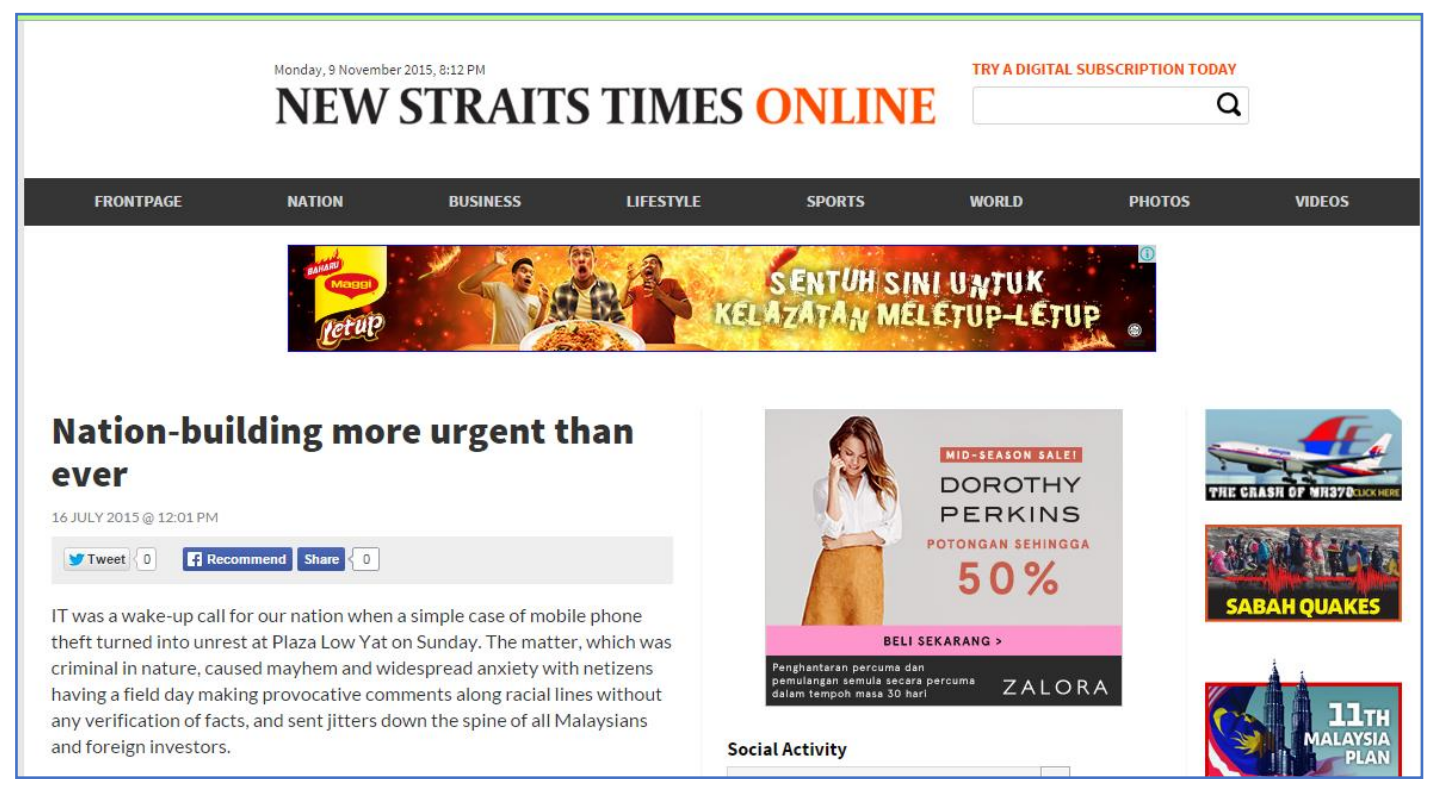

Figure 8: Nation Building

(Source:New Straits Times, 16 July 2015) 
INTERNATIONAL JOURNAL OF ACADEMIC RESEARCH IN BUSINESS AND SOCIAL SCIENCES

Vol. 10, No. 16, Youth and Community Wellbeing: Issues, Challenges and Opportunities for Empowerment V2. 2020, E-ISSN: 2222-6990 @ 2020 HRMARS

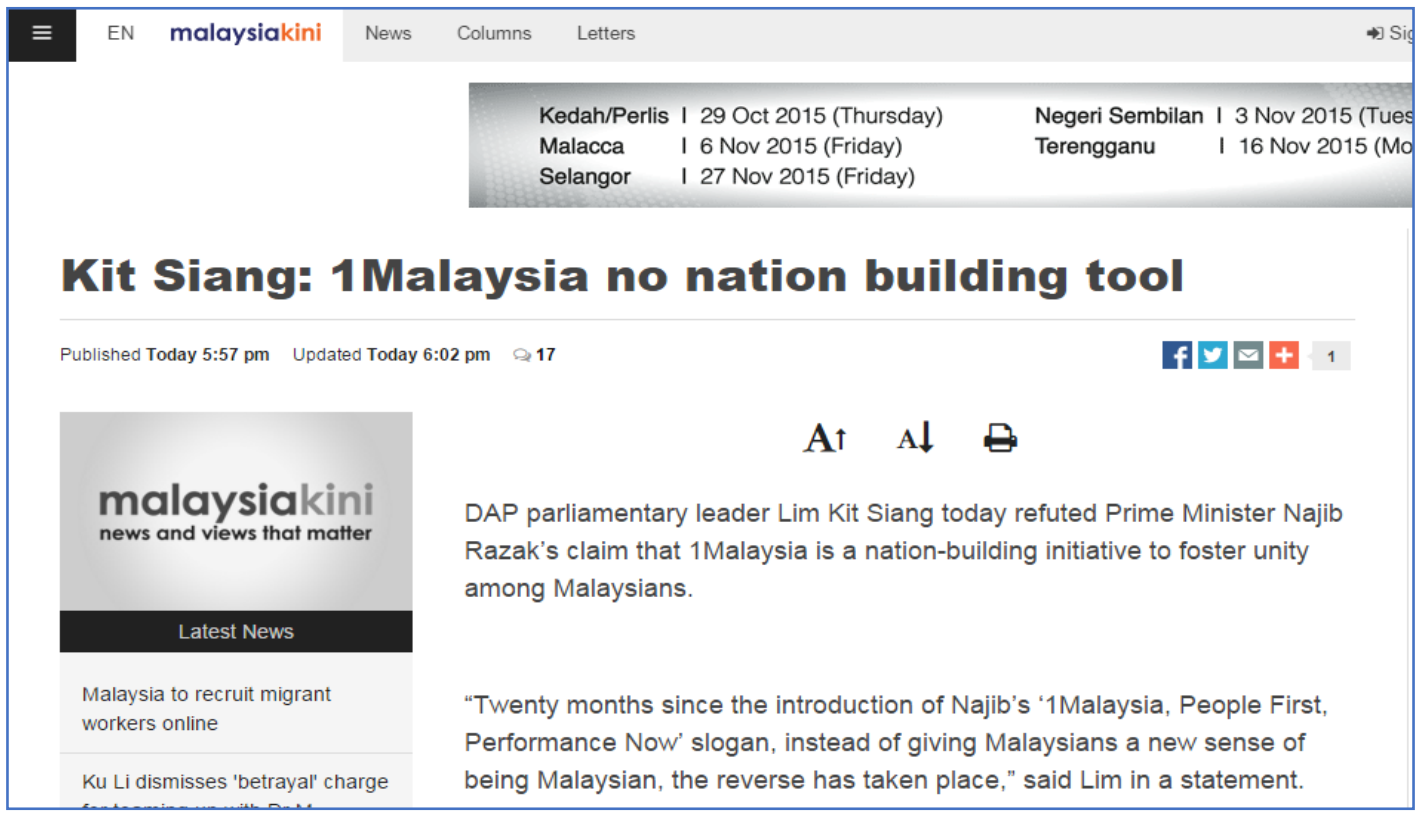

Figure 9: 1Malaysia is No Nation Building Tool

(Source: Malaysiakini.com, 26 December 2010)

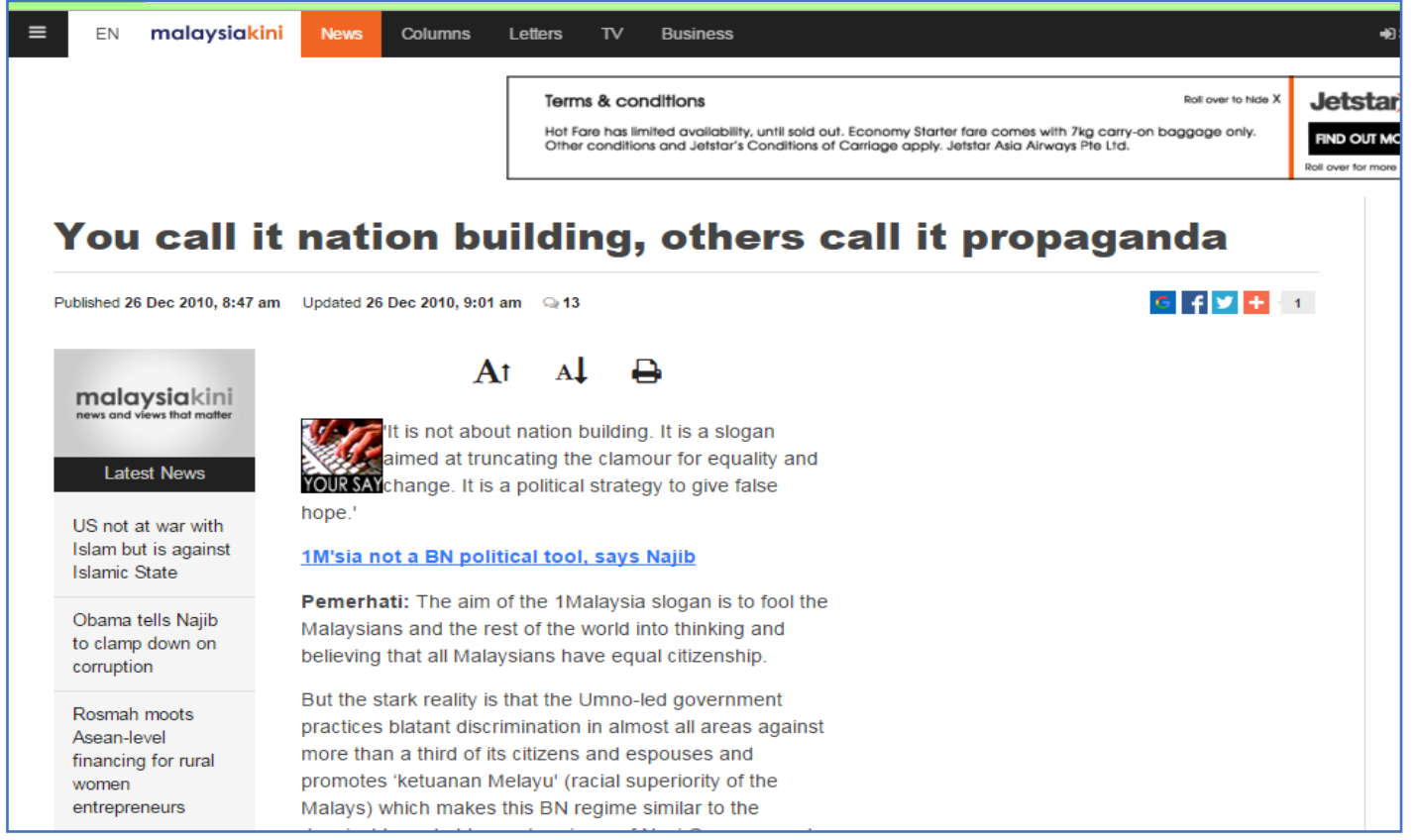

Figure 10: Nation building and propaganda

(Source: Malaysiakini.com, 26 December 2010)

In contradict, Democratic Action Party (DAP) leader, Lim Kit Siang claimed that the 1Malaysia is not a tool for nation building in the statement made in MalaysiaKini on 26 $6^{\text {th }}$ December 2010. He stated that the government, despite its pluralist messages given by the $6^{\text {th }}$ Prime Minister, there is an increase in the irresponsible politicking of racist and religious bigotry which has disappointed the public. He believed that 1 Malaysia concept did not work as planned by the government. From his perspective, 
INTERNATIONAL JOURNAL OF ACADEMIC RESEARCH IN BUSINESS AND SOCIAL SCIENCES

Vol. 10, No. 16, Youth and Community Wellbeing: Issues, Challenges and Opportunities for Empowerment V2. 2020, E-ISSN: 2222-6990 @) 2020 HRMARS

the government plan to foster unity and nation building among Malaysian was a complete failure even just after twenty months of introducing the concept. The statement was also supported by the citizen in a survey done by Malaysiakini.com on $26^{\text {th }}$ December 2010 claiming that the implementation of 1 Malaysia is nothing more than a political ploy or propaganda. Most Malaysian do not believe that the 1 Malaysia concept did not work in creating nation-building. In this matter, we can see that there are two sides of the perception and opinion towards 1Malaysia concept.

\section{The Perception towards 1Malaysia Concept}

\section{The Importance of Racial Harmony and Unity}

The 1Malaysia concept had been widely spread across Malaysia through all sorts of media, including print, broadcast and new media. The promotion of the campaigns has been seen as successful in order to promote their agenda and through this we can see that lots of perception towards the concept either positive or negative. R2 stated:

"I believed that 1Malaysia is good for the society as it can strengthen our unity as we are not the only race in Malaysia but not to forget other race as well. We have long achieved independence, but the unity among races is not yet in a great shape"

The racial unity and harmony in Malaysia has been seen as a serious problem since our independence day. Before the implementation of 1Malaysia, there were lots of other campaigns that being introduced to sustain and strengthen our unity. 1Malaysia is another effort to retain that racial unity and harmony in Malaysia. Unity is a state that being in full agreement. In the context of a nation, unity is a difficult thing to gain, especially in a multi- ethnic's country like Malaysia. It is the government main aim of introducing 1 Malaysia is to unite all its citizens from different background and culture. 1Malaysia concept plays an important role in shaping the diversity and inculcating the common values amongst Malaysian. This was supported by respondent R3:

"Unity is hard to achieve when living in a multiracial country like we are but it is something that we can work on as a loyal citizen. 1Malaysia is another effort by the government, we should stand and support the concept bought for our own benefits"

It's clear that the task to achieve unity in a pluralism society is quite complex. There are lots of aspects to take into consideration. Malaysia with its diverse culture and differences of beliefs need a concept that can help them to achieve the unity without changing the original culture and beliefs. The ethnic tolerance is the key to unite all the ethincs. Our diversity is our strength and assets of the country. It means that we need to think and act as a whole. Even though the government effort to unite and have a stable racial unity seen as a good start at first, but lately there is less and lesser topic to talk about in Malaysia. For instance, R4 claimed that:

"It is not easy to unite all the races together, some of them might have the perception that unity is an important element in sustaining the harmony, but there are lots of people out there that still have a mindset about other races or ethnics, this is why we still trying to achieve that unity" 
INTERNATIONAL JOURNAL OF ACADEMIC RESEARCH IN BUSINESS AND SOCIAL SCIENCES

Vol. 10, No. 16, Youth and Community Wellbeing: Issues, Challenges and Opportunities for Empowerment V2. 2020, E-ISSN: 2222-6990 @) 2020 HRMARS

Thus, unity is a responsibility that are not just in the government's hand, but also refer to all Malaysian. Certain mindset about other racial still a hard thing to put aside, even after 52 years of independence. They have their own opinion on what a certain race is and ignoring other people's opinion. The change in people's mindset need to be done in order to become as one and bring about a common national identity. This had been seen as the challenges that in order to achieve unity and racial harmony. People have their own mindset and what they think about other races and ethnics, and this is not a positive vibe, but it has been passed down in many generations.

Most of the respondents talked about unity. This show that people understand the basic principle that the government try to underline. The 1Malaysia concept is a tool in creating unity and racial harmony. This was supported by the News Straits Times news on $11^{\text {th }}$ September 2015 which talks about molding the harmony in Malaysia. This means that 1 Malaysia concept is being accepted and understand the importance of unity and racial harmony by its people despite the difficulties the government need to handle in achieving its vision.

\section{Question of Fair treatment to all ethnics}

The 1Malaysia concept has been a great debate about the 'One' Malaysia identity. In the concept, unity is key to everything. However, there are issues in the fair treatment to all races and ethnics. R5 pointed that:

"If the government truly wanted the 1Malaysia concept to work, they need to give a fair treatment to all Malaysia regardless their races or ethnics"

As we know, Malays have a special privilege in the constitution. The Article 153 of the Consitution of Malaysia stated all of the privileges that the Malays and Bumiputra have. By implementing the 1Malaysia concept, other races will ask for their right as Malaysian. They believe that if the government wanted to unite all the races and creates one identity and they also need to have the privilege as the Malay and Bumiputra have. The need for fair treatment and equality is an important aspect to look at. Equality as the provision of adequate the opportunities have to all members without discrimination. In is clear that in the 1Malaysia case, the equality needs to be given to all Malaysian and for them to have the same opportunities in term of economic, education and more like the Malays and Bumiputra have. Adding to R3:

"The concept of 'oneness' can create problems for the government and Malays or Bumiputra especially if other races stand up and fight for their right like the Malays' privileges in the constitution."

In contradict, R3's statement will be an issue for the government if other ethnics such as Indians and Chinese trying to get their rights and equality. The article 153 had been a controversial topic to talk about. For the past years, the Chinese and Indian tried to get the same privilege as the Malays. The permanent privilege to the Malays and Bumiputra had been seen as unequal and separate the standard among other races. Indirectly, it can be seen as discrimination among races and ethnics. Even though that is the ongoing issues, the concept of 'oneness' is the perfect opportunity for these 
INTERNATIONAL JOURNAL OF ACADEMIC RESEARCH IN BUSINESS AND SOCIAL SCIENCES

Vol. 10, No. 16, Youth and Community Wellbeing: Issues, Challenges and Opportunities for Empowerment V2. 2020, E-ISSN: 2222-6990 @) 2020 HRMARS

races to fight for the equal treatment from the government because of the concept of 'oneness' that had been widely promoted by the government itself.

\section{Demand of mutual trust and respect}

There are lots of ways in creating the unity. As mention earlier, unity is difficult to achieve in a multi-ethnics, multi- cultures and religions. This uniqueness of Malaysia's diversity had become the strength to the country. R1 argues:

"There is no way in achieving unity if we do not have mutual respect towards other races, it is something important however people keep forgetting about it"

The key towards unity is mutual respect for one another in every aspect of our lives. The failure to respect and trust, others are the reasons why we still try hard to gain and sustain unity. This also could lead to unhealthy and negative environment that can disturb the harmony of the society. Mutual respect had always been the basic fundamental in order to sustain the harmony and peace. This also contributed to the stability of the country. All races in Malaysia had to learn to have mutual understanding, trust and respect for one another and not brought any sensitive issues that can create a negative society. Avoiding any act or action that can insult the customs, religious or culture is a good way to start in creating mutual respect. 1Malaysia implementation help in shaping the mutual respect and later will create the unity that has been the concept main concern.

\section{Malaysia as a nation building tool}

1Malaysia had been closely related to the nation building. The promotion of the concept apart from creating unity, is to build a better nation for the multi-ethnics country. Malaysia is in need of a nation building to unite its people. By introducing the 1 Malaysia concept, it is hoping to create the nation building that Malaysia need. R3 in his statement said:

"In building a nation, many aspects you have to consider and took action. Malaysia with its multi-cultural society sure in need of more attention"

Malaysia always tried to create one nation since its independence day in 1957. The constitution was intended in providing the viable basic ethnic understanding and also good government. Since Malaysia is not only consists of one ethnicity and race, it needs more attention on the nation building. There are many policies being introduced by the government to create the nation building, however we are still a long way in achieving those. Many aspects such as political need to be focused on if we wanted the nation building. Anderson's work on nationalism theory focuses of attention on multi ethnic empire are in need in order to achieve this nationalism. In Malaysia case, we are a multi ethnic country, that is why nation building in Malaysia is difficult to achieve compare to others. We must first create the unity and mutual respect among races. This effort had been made by the UMNO ever since they rule Malaysia and today, the $6^{\text {th }}$ Prime Minister continues the effort in building a nation by implementing 1Malaysia concept. According to MalaysianInsider article on $15^{\text {th }}$ September 2013, inclusive development are very important component in the nation-building process which is based on justice equal rights and respect. It is also mentioned that there is no race-politics and one community superiority over another race. This is what the 1 Malaysia concept is. The importance of unity is seen as the great fundamental in the country to achieve nation- building. 
Nation building is about people. Nation building involves many aspects such as behaviors, language, values, institution to protect and insure the future identity of the nation (Akoto, 2010). It is the deliberate and the energetic projection of the national culture as a whole and also a collective identity. Nation building is a process to unite all of the groups that do not have similarities in terms of social and cultural background into one identity. This is what the government tried to do when they introduced the 1Malaysia concept.

\section{The extent 1Malaysia concept effective towards economy development?}

1Malaysia is not only brought the concept of unity and racial harmony, it also a concept that representing the development of a country. It has helped the economic growth of Malaysia. R6 asserted that:

"People always said that 1Malaysia is to unite all the races and ethnics in Malaysia, well, that is true but there are more than just that. It is a concept to take Malaysia to a new level in the economic growth"

In terms of economic growth, Malaysia is able to unite its people indirectly will help in the country economic. People may not notice that 1 Malaysia can help in growing our ecomonic. This is because the government only highlighted the importance of unity and racial harmony in promoting 1 Malaysia. In order to achieve this, Malaysia needs to unite its people first. R5 said in his statement:

"Economy seems to be a great deal when it comes to country development, we can see if the country development is good through its economy"

Economy plays an important role behind it. In the case of 1Malaysia, the government is trying to boost the country's economy and at the same time will result in the development of Malaysia. Economic inequality should not happen, we cannot leave any of our people behind. The chance must be given to all races fairly without discrimination. There is no place in any race in dominating others. Indirectly, the economy will also get affected and the country development depends on the economy of the country. Apart from that, the government also puts on initiative in helping the lower income by opening Kedai Rakyat 1Malaysia (KR1M), Klinik 1Malaysia and giving out Bantuan Rakyat 1Malaysia (BR1M) which helps those citizens that in need. Even though there are lots of issues regarding this matter from both the opposition parties and also its citizen, the government still believes in their intention of helping and help lighten the burden.

\section{Political impact on country development}

Politics contribute to the country development. The political environment of a country will determine the level of development the country at. It can cause a significant impact, and the government must take action towards the political stability. 1Malaysia has been a quite political issue in the beginning of its introduction. R1 said in his statement:

"Political believe must be set apart in order for the concept to succeed. Fair politics must be given to both government and opposition parties" 
INTERNATIONAL JOURNAL OF ACADEMIC RESEARCH IN BUSINESS AND SOCIAL SCIENCES

Vol. 10, No. 16, Youth and Community Wellbeing: Issues, Challenges and Opportunities for Empowerment V2. 2020, E-ISSN: 2222-6990 @) 2020 HRMARS

Thus, the politicians have to work together in one and not emphasizing on the different races or ethincs. If the politician can work together and put aside the different political believe they can influence Malaysian to work towards what The $6^{\text {th }}$ Prime Minister wants. This will then go one level higher and will turn Malaysia into a great nation. The unity that they create will be seen by the citizen and can be a good influence for them to follow. There must be trust and mutual respect apart from lots of understanding among society and their leaders. Hence, the concept will contribute to the country development indirectly.

\section{What are the government responses towards 1Malaysia? Concept of Malaysia helping the under privilege citizen}

The government under the leadership of Dato' Seri Najib Tun Razak had make an effort to help the under privilege citizen. Under 1Malaysia, there are lots of initiative done by the government. R4 said in his statement:

"Well, in term of helping the under privilege people, the government had done lots of things to lighten their burden. For instance, there are Kedai Rakyat 1Malaysia (KR1M) and also Bantuan Rakyat 1Malaysia (BR1M)"

Within the 1Malaysia concept, the government had made an initiative to set up Kedai Rakyat 1Malaysia, Klinik 1Malaysia, Bantuan Rakyat 1Malaysia and many more. It is to help the under privileged and to lighten the burden. These aims at allowing the lower income family to get the same service, groceries and also medical attention from an expert without paying lots of money. It is also to bring Malaysia closer to the significant of 1 Malaysia. For instance, the opening of the KR1M is helping people in buying the groceries cheaper than the actual market price. According to Utusan Malaysia on $12^{\text {th }}$ January 2012, there are needs for the government to open more of KR1M as the citizen feel the pressure of the increasing price of goods.

Apart from that, the Bantuan Rakyat 1Malaysia (BR1M) also has been one of the government response towards 1 Malaysia concept. The 1Malaysia People's Aid or 'Bantuan Rakyat 1 Malaysia also known as BR1M, is a government scheme that was first established in 2012. The main reason of the BR1M scheme was to offer any help or assistance to household in Malaysia that come from low income group and help them fight with the pressure of the high cost of living. Apart from that, BR1M also may be applied to the unmarried individuals that earn less than a stated amount given and eligible for the scheme. BR1M is a form of financial assistance for the needy and a way for the government to help this group of people. R6 in his statement said:

'These, however being translated by some as a tool to vote buying when referring to $B R 1 M^{\prime \prime}$

In contradict, BR1M had been criticized mainly by the opposition party claiming and questioning this financial assistance as a bribery and also a way for the government to buy the vote from Malaysian. The same view had been opposed by the $4^{\text {th }}$ and $7^{\text {th }}$ Prime Minister of Malaysia, Tun Dr. Mahathir Mohamad claiming that BR1M is nothing but bribing people. According to Sinar Harian (2014), Dr. Mahathir stated that this is his main reason why he strongly opposed the large scale financial 
INTERNATIONAL JOURNAL OF ACADEMIC RESEARCH IN BUSINESS AND SOCIAL SCIENCES

Vol. 10, No. 16, Youth and Community Wellbeing: Issues, Challenges and Opportunities for Empowerment V2. 2020, E-ISSN: 2222-6990 @) 2020 HRMARS

assistance. This in some way makes the government look bad in the eyes of people. The main reason why the government creates BR1M is to help its own people in response of the 1Malaysia concept. The government however, did not react to any of those comments and still giving out BR1M each year.

\section{Safeguard government agenda}

As 1 Malaysia had become a popular topic to talk about after its implementation, there are lots of perception being voice out from Malaysia both from the politicians and also the public. Despite the criticizes about the concept, the governemt stand strong behind the concept and believe that it will work if Malaysian puts their effort in making it happen. R2 said in his statement:

"The government had put lots of effort in making this concept, they believe that the concept will work and will help the country development. Malaysian should stand by the government and support this concept and not criticize it"

Malaysian government had promote the 1 Malaysia concept through every media. The promotion can be seen widely spread across Malaysia. Despite the great promotion and educating Malaysian about the 1Malaysia concept and its goals, many of them still criticize the government and not supporting its implementation. The 1 Malaysia concept is not only being criticize by the people, but also from the politician and mostly are from the opposition parties. However, the government took an action by protecting the concept and believing in it. The government stand strong behind the concept and put lots of effort in order for this to succeed. Thus, any of the statements that are seditious and unrelevent to the government about the 1 Malaysia concept will not be ignored and the government will protect it with their best and believing in the concept.

\section{Conclusion}

The outcome of this research can be used as a reference by all ministry in Malaysia such as the Ministry of Tourism and Culture and also the Ministry of Education which are a body who governs any source of information that is spread to the public. This research paper can be used to find out the perception of Malaysian (Malays, Chinese, Indian) towards 1Malaysia. Malaysia is a multi-ethnics nation, and 1Malaysia as being seen as a device to unite every one of the races and ethnics in Malaysia. This concept stresses on the importance of national unity among people of different races, backgrounds and religious beliefs for the good of all in the future. This is progressing process presented by the $6^{\text {th }}$ Prime Minister of Malaysia, Dato' Seri Najib Tun Razak in 2009. 1Malaysia underlines on ethnic amicability, national solidarity and effective government. This study is carried out to see the person's perception towards 1 Malaysia concept that had been introduced by our $6^{\text {th }}$ Prime Minister. As Malaysia is a multiethnic country made of Malay, Chinese and Indian the perception will differ for each individual. Some people, especially public will agree with these concepts and some will against it. The $6^{\text {th }}$ Prime Minister of Malaysia has come out with the idea of 1Malaysia as a complement to existing approaches to strengthen the unity of the people of various races and achieve a stable economic sector by 2020. Besides that, this study being carried out to see the effectiveness of the 1Malaysia concept to every country's sector. 
INTERNATIONAL JOURNAL OF ACADEMIC RESEARCH IN BUSINESS AND SOCIAL SCIENCES

Vol. 10, No. 16, Youth and Community Wellbeing: Issues, Challenges and Opportunities for Empowerment V2. 2020, E-ISSN: 2222-6990 @) 2020 HRMARS

National identity is a continuous effort by the Malaysian government since 1957 independence. Yet the forming of national identity is complex due conflicts of interest of each ethnic groups in Malaysia. The government has branded the forming of unity as 1 Malaysia concept under the $6^{\text {th }}$ Prime Minister of Malaysia. Though 1 Malaysia been popularised during $6^{\text {th }}$ Prime Minister leadership 2009 to 2018, the context of unity and forming national identity is remained the agenda of any governments that ruling the country. Thus, the new government Perikatan Nasional has formed Unity Ministry which had the elements of 1 Malaysia context in encouraging the unity and harmony in Malaysia. Thus, 1 Malaysia concept and context will remained intact as foundation for Malaysian unity root. Thus this paper will be adding the scholarship values for those studying Malaysian context of unity and harmony with western approach been applied to a country in Southeast Asia. Malaysia is one the perfect example of branding the unity under one I'm really though we are young in our post colonialism comparing with other neighbouring countries.

\section{Corresponding Author}

Dr. Mohd Roslan Rosnon

Institute for Social Science Studies, Universiti Putra Malaysia, 43400 UPM Serdang

Email: roslan_rosnon@upm.edu.my

\section{References}

Altbach, P., \& Knight, J. (2007). The internationalisation of higher education: motivations and realities. Journal of Studies in International Education, 11(4), 290-305.

Anderson, B. (1991). Imagined Communities: Reflections on the Origin and Spread of Nationalism. USA: Verso, London.

Baharuddin, S. A. H. (2008). Many Ethnicities Many Cultures One Nation the Malaysian Experience. Bangi: Institut Kajian Etnik, Universiti Kebangsaan Malaysia.

Braun, V., \& Clarke, V. (2006). Using thematic analysis in psychology. Qualitative Research in Psychology(3), 77-101.

Camara, B. (2002). Ideologies of race and racism. In P. Zarembka (Ed.), Ideologies of Race, and Eminent Economists (Vol. 20, pp. 85-118). Australia: Emerald Group Publishing Limited.

Cheah, K. (2003). The Bumiputera Policy and Nation Building. Journal of Malaysian Studies, 21(1), 339-408.

Chew, P. (2007). Remaking Singapore: language, culture and identity in a globalised world. In A. Tsui \& J. Tollefson (Eds.), Language policy, culture, and identity in Asian contexts (pp. 73-94). New Jersey: Lawrence Erlbaum Associates Publishers.

Efendi, D., Nurmandi, A., \& Agustiyara, A. (2017). State's Labels and the Challenges of Nation-State Building in the Decentralized Politics in Indonesia. Journal of Asian Review of Public Affairs and Policy, 2(3).

Ha, P. L., Kho, J., \& Chng, B. (2013). Nation Building, English As International Language, Medium of Instruction, and Language Debate: Malaysia and possible ways forward. Journal of International and Comparative Education, 2(2), 58-71.

Harris, A., \& Han, A. (2020). 1Malaysia? Young people and everyday multiculturalism in multiracialized Malaysia. Ethnic and Racial Studies, 43(5), 816-834. 
INTERNATIONAL JOURNAL OF ACADEMIC RESEARCH IN BUSINESS AND SOCIAL SCIENCES

Vol. 10, No. 16, Youth and Community Wellbeing: Issues, Challenges and Opportunities for Empowerment V2. 2020, E-ISSN: 2222-6990 @) 2020 HRMARS

Hazri, J., \& Raman, S. R. (2012). Malaysian educational policy for national integration: Contested terrain of multiple aspirations in a multicultural nation. Journal of Language and Culture, 3(1), 20-31.

Ismail, I. Z., \& Ahmad, Z. (2014). A Study of the 1Malaysia Campaign Promotion by Information Department and an Exploratory Survey on the Public Perception. International Journal of Social Science and Humanity, 4(2), 83-87.

James, D. (2003). Nation-Building: the Inescapable Responsibility of the World's Only Superpower. California: RAND Review.

Lapadat, J. C. (2010). Thematic analysis. Encyclopedia of case study research, 2, 925-927.

Lin-Sheng, Y. (2003). The Chinese Dilemma. Australia: East West Pty. Ltd.

Menon, S. J. (2020). Diagnosing Malaysian Multiculturalism: Jo Kukathas and The 1Malaysia Virus. Studies in Global Asias, 6(1), 37-48.

Ministry of Education Malaysia. (1995). Sekolah Wawasan: Konsep Dan Pelaksanaan. Kuala Lumpur: Division of Education Planning, Research and Development, Ministry of Education.

Nurul Ashykin, A. A., Nurul Aien, A. A., Noreem Noor, A. A., Hasbollah, H. R., \& Yaziz, N. A. M. (2015). The Influence of 1 Malaysia Logo Towards Consumers in Malaysia. Paper presented at the Proceedings of the 4th International Seminar on Entrepreneurship and Business (ISEB2015), Flamingo Hotel by the Beach, Penang.

Ortmann, S. (2009). Singapore: The Politics of Inventing National Identity. Journal of Current Southeast Asian Affairs, 28(4), 23-46.

Prime Minister Office. (2010). Government Transformation Programme The Roadmap-Executive Summary. Putrajaya: Unit Pengurusan Prestasi dan Perlaksanaan (PEMANDU).

Radzlan, R., Assim, A. M. I. S., Rosnon, M. R., Baharuddin, S. A., Gill, S. S., \& Badari, Z.S. A. (2018). An Overview of Implicit Racial Stereotype in Malaysia. International Journal of Academic Research in Business and Social Sciences, 8(12), 2128-2135.

Stephenson, C. (2005). "Nation Building." Beyond Intractability. In G. Burgess \& H. Burgess (Eds.), Conflict Information Consortium. Boulder: University of Colorado.

Sufean, H. (1993). Pendidikan di Malaysia: Sejarah, Sistem dan Falsafah. Kuala Lumpur: Dewan Bahasa dan Pustaka.

Suhadi, H. C., \& Abd Rahim, M. H. (2018). Mengukur pencapaian kelestarian Program Transformasi Kerajaan "Gagasan 1Malaysia" dari perspektif belia Malaysia. Jurnal Wacana Sarjana, 2(3), 111.

Suhana, S. (2012). Re-building the Concept of Nation Building in Malaysia. Asian Social Science, 8(4), 115-123.

Tewksbury, R. (2009). Qualitative versus Quantitative Methods: Understanding why qualitative methods are superior to criminology and criminal justice. Theoretical and Philosophical Criminology, 1(1), 38-58.

Husin, W. N. (2011). National-building and 1Malaysia Concept: Ethnic Relations Challenges in the Educational Field. International Journal of Humanities and Social Science, 1(9), 228-237.

Teh, W. H. (1983). Race Relations in Malaysia. Kuala Lumpur: Heinemann Educational Books (Asia) Ltd.

Wang, Z. (2009). Nation building, state building, and the road to democracy: political development in 60 years of the people's republic. China Policy Institute Briefing Series, Volume 54. Nottingham: China Policy Institute, University of Nottingham. 